\title{
Optimization of Green Infrastructure Network in Fengdong New Town Based on MSPA and MCR Model
}

\author{
Ting Wang, Yunying Ren \\ Department of Urban and Rural Planning, School of Architecture, Xi 'an University of Architecture and Technology, Xi 'an, China
}

Email address:

577884340@qq.com (Ting Wang), 844568296@qq.com (Yunying Ren)

\section{To cite this article:}

Ting Wang, Yunying Ren. Optimization of Green Infrastructure Network in Fengdong New Town Based on MSPA and MCR Model. Science Discovery. Vol. 9, No. 5, 2021, pp. 226-233. doi: 10.11648/j.sd.20210905.15

Received: September 9, 2021; Accepted: October 14, 2021; Published: October 19, 2021

\begin{abstract}
The concept of life community integrating "mountains, rivers, forests, farmlands, lakes, and grasslands", proposed by the Chinese government, emphasizes the protection and restoration of ecosystem integrity. The construction of green infrastructure (GI) network can connect fragmented habitats, improve landscape connectivity, optimize ecological network, and thus maintain ecological security in the region. In addition, different from the ecological network, the GI network can establish a network structure with composite functions, better enrich regional biodiversity, protect historical and cultural resources, and guide rational development of leisure spaces. Taking Fengdong New Town of Xixianxi district in Xi'an as the research object and aiming at the composite functions of the GI network, this study analyzed the status quo of GI network construction by comprehensively using morphological spatial pattern analysis (MSPA), landscape connectivity analysis, and the minimum cumulative resistance (MCR) model. The following conclusions are drawn: (1) the distribution of green infrastructure in the research area is extremely uneven, the landscape is seriously fragmented, (2) the southern part of the research area has the most core sources and the best connectivity, there is no core source in the middle and east of the site, the connection also is poor, the ecological source distribution in the east and north of the site is more, but the fragmentation is serious and the connectivity is poor. Based on the above analysis results, the Optimization strategies were also proposed for the GI network in the study area, which involved adding more ecological sources and links, strengthening the construction of sites, and improving the integrity of the comprehensive GI network.
\end{abstract}

Keywords: Green Infrastructure (GI) Network, Morphological Spatial Pattern Analysis (MSPA), Landscape Connectivity, Minimum Cumulative Resistance (MCR) Model, Fengdong New Town

\section{基于MSPA和MCR模型的浅东新城绿色基础设施网络优化研究}

\section{王婷, 任云英}

西安建筑科技大学建筑学院, 西安, 中国

邮箱

577884340@qq.com（王婷）, 844568296@qq.com（任云英）

\begin{abstract}
摘要：国家所提出的“山水林田湖草”的生命共同体，强调了对生态系统整体性的保护与修复，构建绿色基础设施（GI） 网络可以连接破碎生境, 提高景观连通性, 优化生态网络, 进而维护区域生态安全。此外绿色基础设施网络区别于生 态网络, 可以建立起复合功能的网络结构, 更好地丰富区域生物多样性、保护历史文化资源、引导休闲游䟤空间的合 理发展。此次研究以西安西咸新区浅东新城为对象, 基于 GI网络的复合功能目标导向, 综合运用形态学空间格局分析 (MSPA)、景观连通性分析、最小累积阻力模型（MCR）等方法分析了 GI网络建设现状, 得出以下结论: (1) 研究区 的绿色基础设施分布极度不均匀, 景观破碎化严重; (2) 研究区南部核心源地最多、连接性最好, 场地中部及东部没 有核心源地、连接性差; 场地东部和北部生态源地分布较多, 但破碎化严重, 连接性较差。基于以上分析结果, 对研 究区的GI网络提出增加生态源地和连接廊道、加强小场地建设、提高综合GI网络完整性的优化策略。
\end{abstract}


关键词: 绿色基础设施网络, MSPA, 景观连通性, MCR模型, 浅东新城

\section{1. 前言}

随着城市化进程的加速，城乡原有的森林、河流、湖泊、 草地等自然生境斑块必然受到城市扩张的影响, 呈现不断减 少、破碎化的趋势, 连接性不断下降[1]。生态系统的健康完 整性遭到破坏, 城市生态系统服务功能和生物多样性保护都 受到严重影响 $[2 ， 3]$ 。作为自然生命支撑系统的绿色基础设 施（Green Infrastructure）网络的构建显得尤为迫切[4], GI 是由城乡一切自然、半自然和人工的开敞绿地、湿地及水域 所组成的相互连接的空间网络, 由网络中心 (hub) 和连接 廊道（link）构成以及小场地（Site）构成, 用以保护自然生 态系统价值和功能, 维持清洁的空气和水, 保护人类和生物 的广泛利益[5]。并且相较于生态网络、绿道、景观格局等概 念, 绿色基础设施涵盖的范围更为广泛, 不仅可以维系自然 生态系统的价值和功能, 提升人类福祉, 还为未来土地开发 和城市发展提供了一个精明保护的策略[6]。

目前，针对绿色基础设施网络构建的方法主要有“千 层饼”叠加法、生态绩效法、廊道连通性评估法和形态学 格局分析法[7]。“千层饼”叠加法是基于传统生态学理论, 选取植被、地质、水文、动物等因子进行垂直叠加, 并且 根据现有的林地、水体等生态源地, 叠加得出绿色基础设 施网络结构, 这种模式开启了景观客观分析的时代, 但存 在着理论的唯自然论和方法的唯技术论, 现在很少单独使 用; 生态绩效法更关注生态的水平生态过程, 确定空间中 的生态关键作用点, 根据土地利用类型、植被覆盖、高程 等因素设置阻力值, 并利用GIS中的“最小阻力距离”模型 (MCR) 进行潜在廊道识别, 形成绿色基础设施网络 [8]; 廊道连通性评估法是基于图论和网络拓扑分析, 将动物栖 息地和生物迁徙廊道等抽象成不同的网络拓扑结构 [9], 再
对廊道进行连通性分析, 选取连通性高、阻力小的廊道进 行连接形成绿色基础设施网络[10]; 但以上方法在生态源 地的选取上多以绿地性质、尺度等自身属性为依据, 存在 一定主观性。近年，一种偏向于景观结构层面的形态学空 间格局分析 (Morphological spatial pattern analysis) 方法 被引入对绿色基础设施网络的评价和构建研究中来 [11-14], MSPA 能够较为科学地考察各斑块在景观中的连 通功能, 弥补了传统方法的不足, 使生态源地和生态廊道 的选取更为科学 $[15,16]$ 。

MSPA法是利用腐蚀、扩张、开运算、闭运算将图形 进行分割、识别、分类等图像处理方法[17], 不同于传统 的将斑块或者廊道单独提取出来进行分析的方法, 形态学 方法是从像元的层面上识别出研究区内重要的生境斑块 和廊道等对景观连通性起重要作用的区域, 它将二值图像 分割成互不重叠的7种类型：核心区(Core)、孤岛(Islet)、 桥接(Bridge)、环道(Loop)、边缘(Edge)、穿孔(Perforation) 和支线(Branch)（表1），该方法强调结构性连接，仅依赖 于土地利用数据, 将其重新分类后提取林地、湿地等自然 生态要素作为前景, 其他用地类型作为背景, 即可得到强 调结构性连接且景观结构类型精确的重分类图, 其较早用 于生态网络、森林景观格局等方面研究。此外, 绿色基础 设施网络除了生态功能, 在景观、文化的审美与游憩; 以 及与人类福祉相关的健康、生活需求、社交等诸多方面都 有重要意义, 所以本文在MSPA方法的基础上结合MCR模 型, 通过乡土文化遗产景观适宜性评价, 识别重要的景区、 乡土文化遗址源地, 建立文化遗产廊道和旅游游息线路, 构建研究区多功能复合型的绿色基础设施网络图谱, 对浲 东新城现有绿色基础设施格局进行优化。

表1 MSPA 的景观类型及其含义。

\begin{tabular}{|c|c|}
\hline MSPA要素 & 生态学含义 \\
\hline 核心区 & 大型自然斑块，是多种生态过程的“源”，为野生动物提供栖息地或迁移目的地。 \\
\hline 孤岛 & $\begin{array}{l}\text { 孤立的小斑块, 其内部物种和外部物种交流的可能性较小, 相当于生态网络中的“生态跳岛”, 可提供物种散布或物质、能量流动, } \\
\text { 在生态网络中起着媒介的作用。 }\end{array}$ \\
\hline 边缘区 & 核心区与其外围城市建设用地斑块的过渡地带, 保护核心区的生态过程和自然演替, 减少外界景观人为干扰带来的冲击, 具有边 \\
\hline 孔隙 & $\begin{array}{l}\text { 核心区与其内部城市建设用地斑块的过渡地带, 同样具有边缘效应, 是核心区绿色景观受到人类活动影响或者自然条件的影响而 } \\
\text { 出现植被退化的边缘地带。 }\end{array}$ \\
\hline 桥接区 & $\begin{array}{l}\text { 连通核心区的狭长区域, 是相邻核心区斑块间进行物种扩散和能量交流的通道, 代表生态网络中斑块连接的廊道, 对生物迁移和 } \\
\text { 京观连接具有重要的意义。 }\end{array}$ \\
\hline $\begin{array}{l}\text { 环岛区 } \\
\text { 支线 }\end{array}$ & $\begin{array}{l}\text { 连接同一核心区内部的廊道, 是核心区斑块内部进行物种扩散和能量交流的通道。 } \\
\text { 只有一端与边缘区、桥接区、环道区或者孔隙相连的区域。 }\end{array}$ \\
\hline
\end{tabular}

\section{2. 研究区域与研究方法}

\section{1. 研究区概况}

浅东新城位于西安市西部, 是西咸新区渭河南岸的重 要组成部分, 面积 $159.3 \mathrm{~km}^{2}$ 。属暖温带半湿润大陆性季风 气候区, 四季冷暖干湿分明, 光、热、水资源丰富, 区内
然降水量年际变化大, 季节分配不匀, 雨量多集中在7、8、 9月份。属于关中平原，地处新生代渭河断陷盆地中部西 安凹陷的北侧, 地势平坦, 土地肥沃，新城内共有4条河 流流经，分别为渭河、浅河、皇河和太平河，沿渭河和浅 河流域拥有丰富的湿地资源。浅东新城还拥有丰富的历史 文化遗产资源，自北向南有汉建章宫与太液池遗址、秦阿 
房宫遗址、周镐京遗址、唐昆明湖遗址等，具有极高的保 护开发价值。

浅东新城拥有优越的自然条件, 但是随着新区开发建 设, 城市化进程迅速加快, 自然生态斑块数量减少, 破碎
化程度加剧, 与之带来的各种生态环境问题日益突出。在 城市土地资源有限, 难以大规模建设生态用地的背景下, 尽可能利用现有绿色基础设施, 重建其空间生态连接, 优 化绿色基础设施的网络结构。
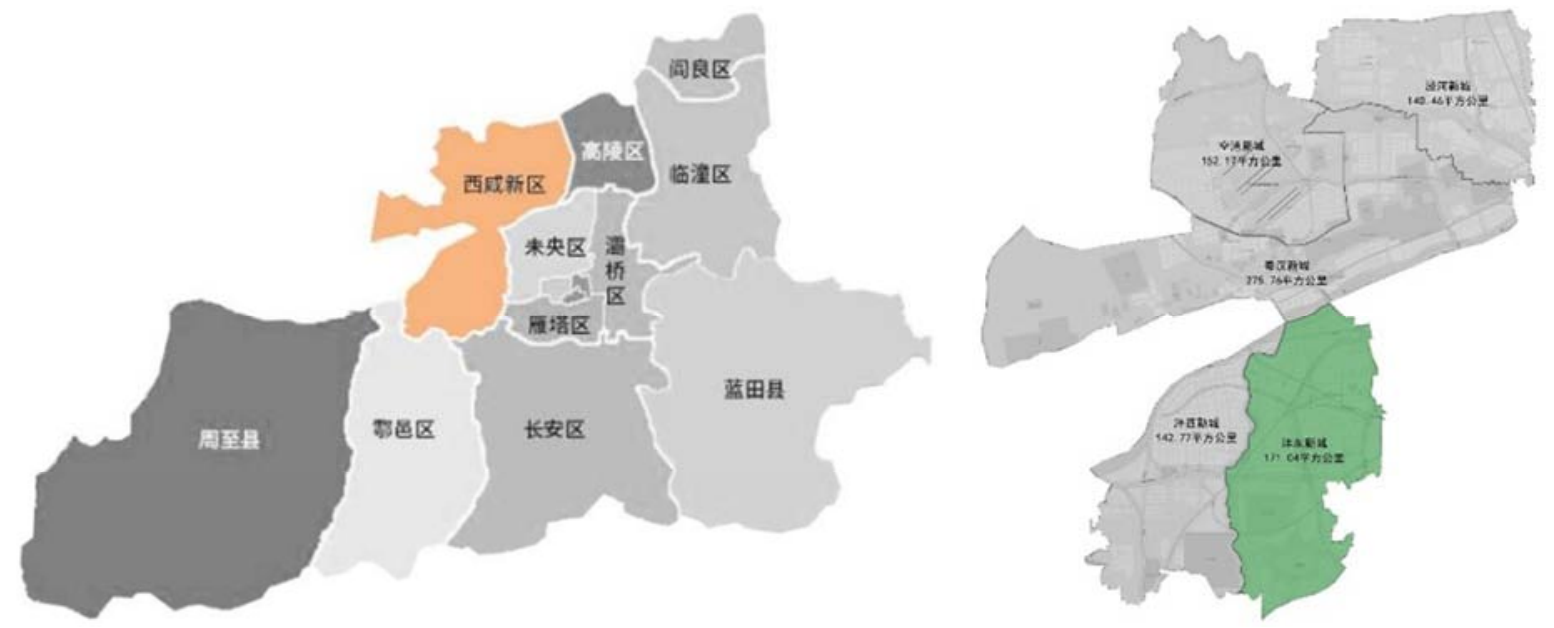

图1 研究区位置。

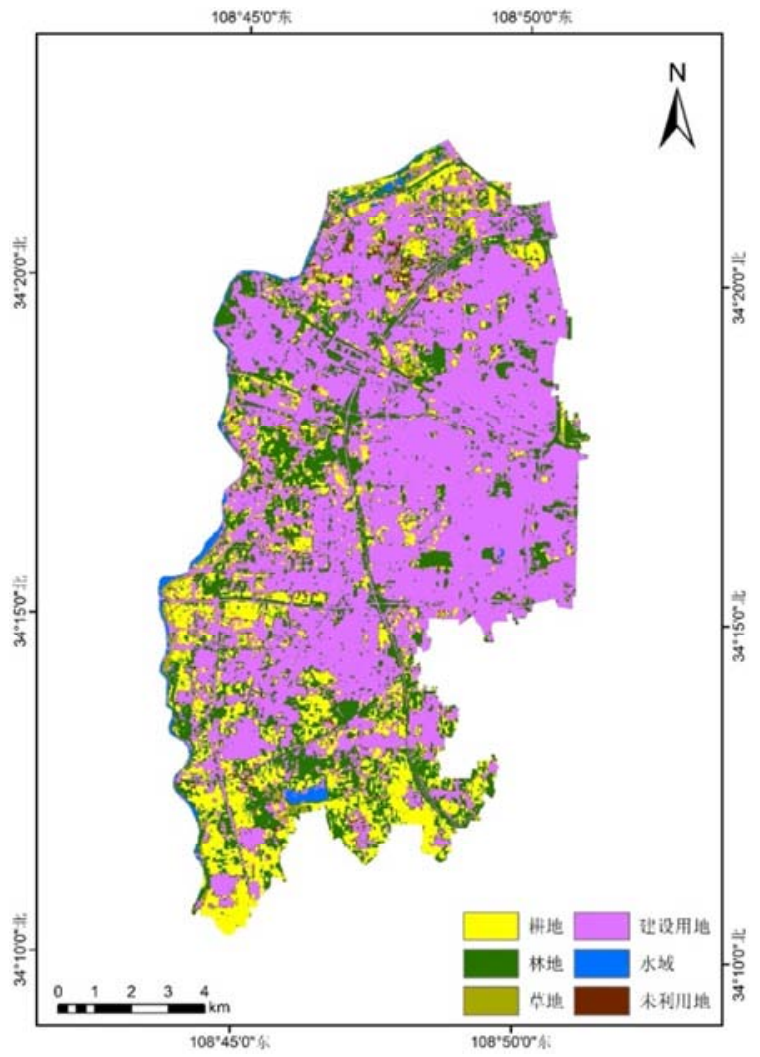

图2 研究区土地利用现状图。

\section{2. 数据来源与预处理}

本研究选用2020年的Landsat8遥感影像图和“哨兵2号” 遥感影像图, 为了减小云量、植被等因素对解译结果的影 响, 选择5月、7月、11月运量小于 1 的遥感图像, 随后在 ENVI5.3软件中对影像进行预处理, 经过辐射定标-大气较 正-多光谱融合-裁剪步骤, 然后采用随机森林分类法, 对
三个月份遥感影像进行对比分类, 采用这个分类法可以更 加准确的得出解译结果, 最后结合目视解译法及进行野外 实地调研, 对解译结果进行校正, 获得 $10 \mathrm{~m} * 10 \mathrm{~m}$ 精度的土 地利用类型现状图, 将浅东新城土地利用现状分为林地、 草地、农田、水体、裸地及建设用地6大类。并收集了西 咸新区城市总体规划（2016-2030）、浅东新城分区规划 （2010-2020）规划图及文本辅助绿色基础设施网络构建。

\section{3. 研究方法}

\subsection{1. 基于MSPA方法的绿色基础设施格局分析}

运用MSPA法识别绿色基础设施源地最关键的是划分 图像中GI图元与非GI图元。根据绿色基础设施的内涵和生 态系统服务功能, 将林地、水体、草地和耕地作为绿色基 础设施的主要构成要素, 在ArcGIS中将其重分类合并为前 景, 赋值为 2 ; 将其余用地类型作为背景, 赋值为 1 , 将栅 格数据大小设定为 $10 \mathrm{~m} \times 10 \mathrm{~m}$, 可以保留研究区重要的景观 要素, 满足研究数据精度要求, 并将数据转为TIFF格式的 二值栅格数据文件, 导入Guidos分析软件。参数设置选择 八邻域规则, 边缘宽度设为 1 , 通过 Image Analysis-Pattern-Morphological-MSPA分析, 得到互不重叠 的七类景观（图3），对分析结果进行统计（表2）。

表2 MSPA要素面积统计表。

\begin{tabular}{lll}
\hline 类型 & 面积 $\left(\mathbf{h m}^{\mathbf{2}}\right)$ & 占GI总面积的比例 $(\boldsymbol{\%})$ \\
\hline 核心 Core & 4918.38 & 75 \\
桥接 Bridge & 55.87 & 0.81 \\
孤岛 Islet & 50.16 & 0.76 \\
孔隙 Perforation & 245.29 & 3.8 \\
环岛 Loop & 47.78 & 0.74 \\
支线 Branh & 146.02 & 2.24 \\
边缘 Edge & 1092.07 & 16.65 \\
总计 Total & 6555.57 & 100 \\
\hline
\end{tabular}




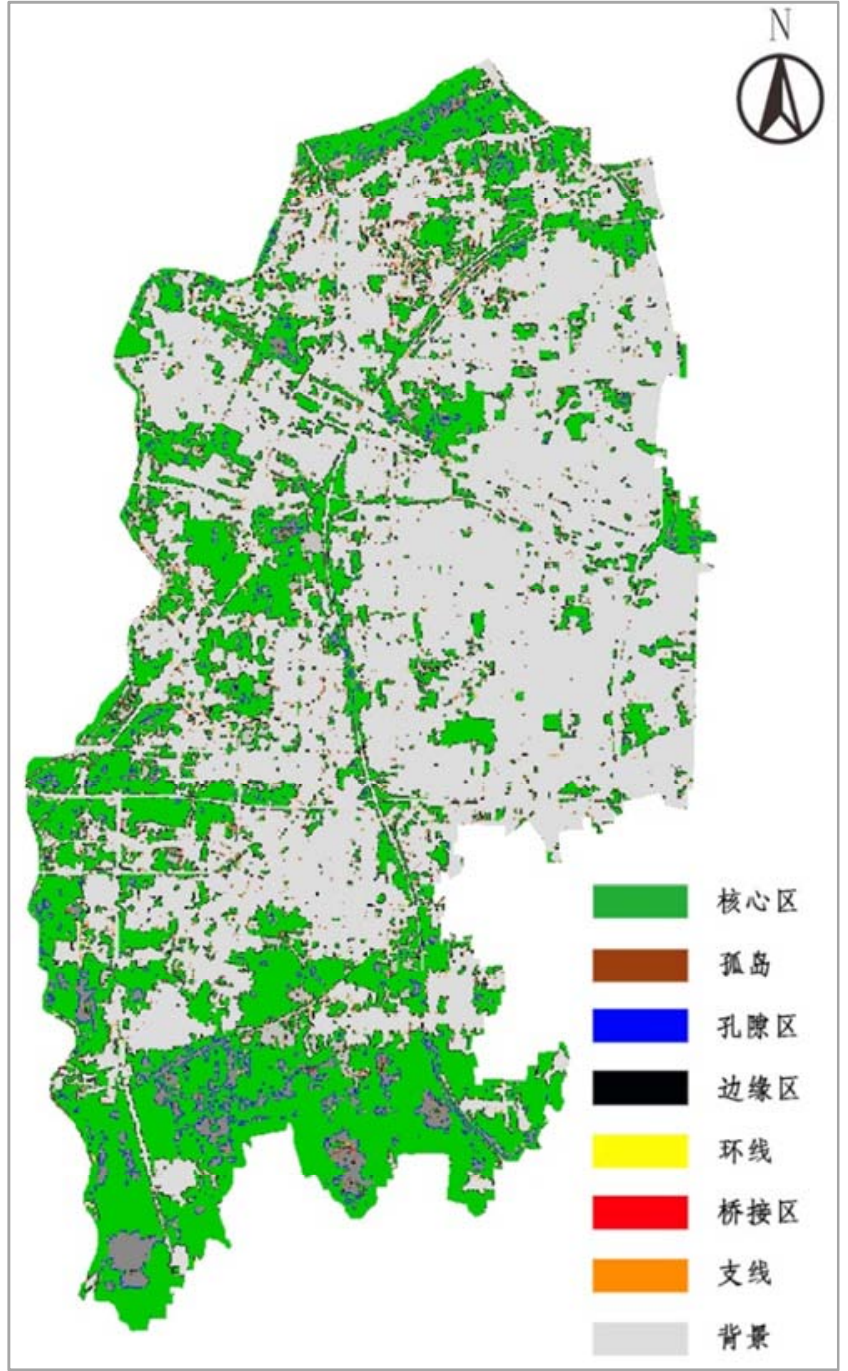

图3 MSPA景观类型图。

\subsection{2. 基于Conefor的绿色基础设施连通性分析}

根据福尔曼提出的最优景观生态格局“集聚有离析” 模式[19], 最优的绿色基础设施网络格局应有大型自然植 被斑块用以涵养水源, 保证关键物种的生存, 维持生物多 样性; 以及足够宽和一定数量的连接廊道用于动植物的扩 散及物质和能量的流动; 还需要有一些面积较小的自然植 被斑块, 用作物种暂时的栖息地及避难所。所以, 本研究 将面积为 3 公顷以上的核心斑块作为生态源地, 将连接桥、 环、分支等作为连接廊道, 将小面积的核心区和孤岛作为 小型自然植被斑块。

本研究通过Conefor2.6软件对面积大于 3 公顷的生态 源地进行景观连通性分析, 选择最具代表性的整体连通性 (IIC, 公式1)、可能连通性(PC, 公式2) 2 个景观指数, 设 置连接距离阈值为 $500 \mathrm{~m}$, 连通的概率为 0.5 , 对所选斑块 进行景观连接度评价, 将核心区 $\mathrm{dPC}$ 值大于 1 的 13 个斑块作 为核心源地 (表 3 )。将剩余的核心区分为重要核心区 $(0.5$ $<\mathrm{dPC}<1)$, 一般核心区 $(\mathrm{dPC}<0.5)$, 将桥接区分为极重 要桥接区 $(\mathrm{dPC}>2)$, 重要桥接区 $(0.5<\mathrm{dPC}<2)$ ，一般桥 接区 $(\mathrm{dPC}<0.5)$ 。

$$
\begin{gathered}
\mathrm{HC}=\frac{\sum_{i=1}^{\mathrm{n}} \sum_{j=1}^{n} \frac{a_{i} \bullet a_{j}}{1+n I_{i j}}}{A_{L}^{2}} \\
\mathrm{PC}=\frac{\sum_{i=1}^{n} \sum_{j=1}^{n} p_{i j}^{*} \bullet a_{i} \bullet a_{j}}{\mathrm{~A}_{\mathrm{L}}^{2}}
\end{gathered}
$$

式中, $\mathrm{n}$ 表示景观中斑块总数, $\mathrm{a}_{i}$ 和 $\mathrm{a}_{j}$ 分别表示斑块 $i$ 和斑块 $j$ 的面积, $\mathrm{nl}_{i j}$ 表示斑块 $i$ 和斑块 $j$ 之间的连接, $\mathrm{A}_{L}$ 是景 观的总面积, $\mathrm{p}_{i j}^{*}$ 是物种在斑块 $i$ 和 $j$ 直接扩散的最大可能性。 I为某一景观的连接度指数值, 本文指整体连通性指数(IIC) 和可能连通性指数(PC); $I_{\text {remove }}$ 为将斑块 $i$ 从该景观中剔除后, 景观的连接度指数值。

表3 生态源地景观连通性指数统计表。

\begin{tabular}{llll}
\hline 排序 & 编号 & dPC & dIIC \\
\hline 1 & 12 & 81.3 & 82.35 \\
2 & 13 & 26.91 & 19.01 \\
3 & 11 & 21.88 & 14.91 \\
4 & 6 & 4.86 & 4.27 \\
5 & 10 & 3.42 & 1.77 \\
6 & 4 & 3.22 & 2.46 \\
7 & 5 & 2.75 & 2.06 \\
8 & 9 & 2.45 & 1.58 \\
9 & 1 & 1.97 & 2.04 \\
10 & 3 & 1.86 & 1.48 \\
11 & 7 & 1.44 & 1.01 \\
12 & 2 & 1.18 & 1.15 \\
13 & 8 & 1.04 & 0.75 \\
\hline
\end{tabular}

\subsection{3. 基于MCR模型的绿色基础设施廊道提取分析}

最小累积阻力模型 (Minimum Cumulative Resistance, MCR）起源于物种扩散过程的研究, 是指物种从源到目的 地运动过程中所需耗费代价的模型[20]。本研究基于MCR 模型构 建廊道分为两方面: 基于动植物生存迁徙的最佳 路径的生态廊道和基于历史文化遗产的乡土文化景观游 馝廊道。

\section{（1）生态廊道构建}

首先, 结合 MSPA 和景观连接度评价结果, 将绿色 基础设施核心区和桥接区等生态网络中的结构性要素作 为研究区的核心景观, 综合考察不同土地利用类型对物种 生存、繁殖、迁徙的影响, 确定了不同生境斑块与土地利 用类型的景观阻力值 (表4), 构建了研究区的阻力面。 然后, 基于最小阻力模型 (MCR) 构建了研究区 26 个生态 源地斑块间的潜在生态廊道, 其中 13 个为核心源地 ( dPC $>1$ ), 得到研究区的潜在生态网络。 
表4 生态廊道景观阻力值。

\begin{tabular}{|c|c|c|c|}
\hline 阻力因子 & 分级指标 & 阻力值 & 权重 \\
\hline \multirow{6}{*}{ 土地利用类型 } & 林地 & 10 & \multirow{6}{*}{0.43} \\
\hline & 水体 & 10 & \\
\hline & 草地 & 50 & \\
\hline & 农田 & 100 & \\
\hline & 建设用地 & 200 & \\
\hline & 裸地 & 200 & \\
\hline \multirow{8}{*}{ MSPA景观类型 } & 核心区 & 5 & \multirow{8}{*}{0.36} \\
\hline & 桥接区 & 10 & \\
\hline & 环岛 & 30 & \\
\hline & 支线 & 40 & \\
\hline & 孤岛 & 50 & \\
\hline & 边缘 & 70 & \\
\hline & 孔隙 & 100 & \\
\hline & 背景 & 200 & \\
\hline \multirow{3}{*}{ 道路类型 } & 一级路（高速、国道、省道、铁路） & 200 & \multirow{3}{*}{0.21} \\
\hline & 二级路 & 100 & \\
\hline & 三级路 & 50 & \\
\hline
\end{tabular}

表5 研究区景观资源统计。

\begin{tabular}{lll}
\hline 景观类型 & 自然景观 & 人文景观（历史文化遗产） \\
\hline \multirow{2}{*}{ 景观名称 } & 浅渭湿地公园、浅河森林公园、涟东泮河生态景区、涟东农 & 建章宫遗址区、阿房宫遗址区、太液池遗址区、汉城遗址区、 \\
& 博园、昆明池生态区、红光公园、云水公园 & 镐京遗址区、丰京遗址区、昆明池生态区 \\
\hline
\end{tabular}

（2）景观游憩廊道构建

通过MCR模型模拟了主体 (体验者) 沿一定的路径和 场所, 对文化遗产体验和感知的过程。这种体验感知过程 可以被理解为一种在空间上水平运动的过程, 即用不同景 观要素对遗产休闲活动构成的阻力来模拟 [21]。研究区内 拥有丰富的自然人文景观资源, 首先对研究区内自然景观 和人文景观进行梳理（表5），在绿色基础设施生态网络 图谱基础上, 确定绿色基础设施网络中的主导节点即核心
景观（源地）, 强调其在综合网络中的核心和枢纽作用。 然后, 基于土地利用类型、道路等级和距离道路的距离构 建了游䪹廊道景观阻力值（表6），通过成本路径工具构 建生态休闲类景观节点和历史文化类资源节点之间的潜 在联系廊道, 获取研究区的自然景观廊道和人文游憩廊道。 最后, 将绿色基础设施生态网络以及绿色基础设施人文游 憩网络进行叠加, 得出绿色基础设施综合网络模式。

表6 游覣廊道景观阻力值。

\begin{tabular}{|c|c|c|c|}
\hline 阻力因子 & 分级指标 & 阻力值 & 权重 \\
\hline \multirow{6}{*}{ 土地利用类型 } & 林地 & 10 & \multirow{6}{*}{0.4} \\
\hline & 水体 & 10 & \\
\hline & 草地 & 50 & \\
\hline & 农田 & 100 & \\
\hline & 建设用地 & 200 & \\
\hline & 裸地 & 200 & \\
\hline \multirow{4}{*}{ 道路类型 } & 一级路（高速、国道、省道、铁路） & 200 & \multirow{4}{*}{0.35} \\
\hline & 二级路 & 100 & \\
\hline & 三级路 & 50 & \\
\hline & 四级路 & 10 & \\
\hline \multirow{3}{*}{ 距离最近道路距离 $(\mathrm{m})$} & $<200$ & 5 & \multirow{3}{*}{0.25} \\
\hline & $200-500$ & 30 & \\
\hline & $\begin{array}{l}500-1000 \\
>1000\end{array}$ & $\begin{array}{l}50 \\
100\end{array}$ & \\
\hline
\end{tabular}

\section{3. 结果与分析}

\section{1. 基于MSPA的绿色基础设施格局分析}

由图3和表2, 可以分析得出, 核心区是研究区绿色基 础设施最主要的组成要素, 面积为 $4918.38 \mathrm{hm}^{2}$, 占GI总面 积的 $75 \%$, 但是核心区分布的位置非常不均衡, 主要集中 于渭河和泮河沿岸以及南部区域, 研究区东部核心区斑块
相对较少, 且分布较为分散, 连通性较差。桥接区作为生 物非常重要的迁徙廊道, 面积仅为 $55.87 \mathrm{hm}^{2}$, 仅占GI总面 积 $0.81 \%$, 可以看出研究区内斑块破碎化严重, 斑块间连 通性差, 急需增加桥接区。边缘区是核心斑块的外部边缘, 也是核心区的缓冲区, 孔隙是核心斑块的内部边缘, 二者 分别占GI总面积的 $16.65 \%$ 和 $3.8 \%$, 说明边缘区的面积比较 大, 具有较强的边缘效应。孤岛相当于绿色基础设施网络 中的“小场地”, 是动物迁徙过程中的“踏脚石”, 分布比较 
零散, 其面积为 $50.16 \mathrm{hm}^{2}$, 占GI总面积的 $0.76 \%$, 应适当 增加孤岛的数量和面积。

\section{2. 绿色基础设施连通性分析}

根据表 3 和图 3 可以看出, 研究区内共有 13 个核心区 $\mathrm{dPC}$ 值大于 1,12 个核心区的 $\mathrm{dIIC}$ 值大于 1 , 连通性最好的核 心源地位于研究区的南部, 为水域和农田, 源地面积较大 且多桥接区, 连通性高。研究区西部沿泮河河道也有若干 连通性较好的源地, 呈带状分布, 面积较大, 分布较为破 碎化, 生物多样性高, 这些核心源地在绿色基础设施网络 中既起到了物种栖息地的作用, 又起到了连接廊道的作用, 增强了景观的连通性。北部渭河河段也有一块面积较大的 核心源地, 自身连通性好, 但是十分孤立, 与其他源地间 没有连通。研究区中部和东部主要为建设用地, 没有 $\mathrm{dPC}$ 大于 1 的核心区, 面积都较小, 空间分布分散, 连通性较 差, 急需增加连接廊道和生态源地。

\section{3. 综合绿色基础设施网络格局分析}

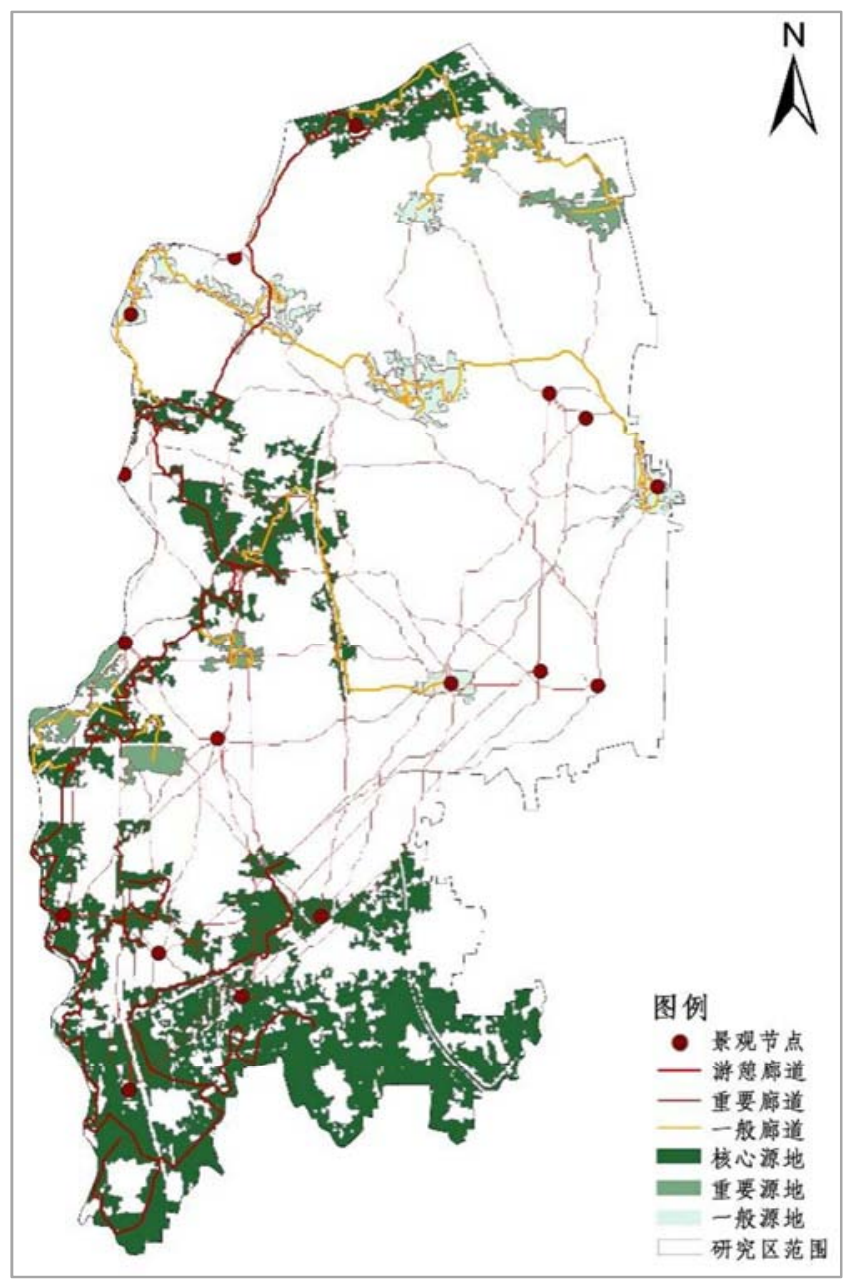

图4 综合GI网络格局。

由图3可以看出, 浅东新城内建设用地占绝大面积, 生态用地受到严重的侵占, 绿色基础设施网络不完整, 呈 现高度破碎化。从整体上看（图4），GI网络在研究区西 南和南部呈现比较好的状态, 这里受城市开发建设影响较
小, 保留大片农田、水域等生态用地, 核心生态源地多, 面积大, 生态服务价值高, 连接廊道都为重要廊道, 连通 性高, 因为斑块较为完整, 所以小场地（踏脚石）较少。 此外, 这里还拥有昆明湖、浅东农博园、云水公园、镐京 遗址等众多景观, 人文、自然游悡资源丰富。研究区北部 和西部渭河沿岸和浅河沿岸的GI网络呈线性分布, 生态源 地较多, 但是核心源地的占比不是很高, 斑块破碎化较严 重, 连接廊道既有主要廊道, 也有一般廊道, 连通性较南 部相比较低, 小场地较多, 为物种迁徙提供了很好的场所, 这里生物多样性较高。渭河和浅河沿岸分布着泮渭湿地公 园、泮河森林公园、浅河生态景区、诗经里小镇等景观, 以自然景观资源为主, 游息廊道建设情况较好。研究区的 中部和东部为城市建设用地, 没有大型核心生态源地, 现 有的源地基本上为公园绿地, 也没有重要连接廊道, 斑块 破碎化严重, 小场地数量多, 但是缺少大型生态源地, 导 致生态服务价值不高, GI网络缺失, 急需增补。该区域的 游秝景观也相对较少, 基本为中小型公园和遗址公园, 如 阿房宫遗址公园、红光公园等, 但是这里路网密集, 游悡 廊道较多。总体而言, 浅东新城自然生态本底较好, 但是 城市快速建设对生态用地破坏较大, 在研究区中东部急需 增加生态源地和连接廊道, 西南部在现有基础上增加连接 廊道和小场地, 使 $\mathrm{GI}$ 网络更加完整, 北部急需增加与其他 区域的连接廊道。

\section{GI网络优化的策略与建议}

\section{1. 增加生态源地与连接廊道}

生态源地对一个地区的生态功能提供及景观连通性 具有至关重要的意义。本研究将浅东新城内的绿色基础设 施网络中心分为三级——核心源地、重要源地及一般源地。 核心源地是新城内面积大、连通性好的大型生态用地, 生 物多样性高, 承担着极为重要的生态服务功能, 在建设时 应严格划定生态保护红线, 为生物提供多样的栖息地, 并 成为城市的生态屏障。重要源地和一般源地面积相对较小, 分布较为破碎, 多为城市公园、社区公园等, 在建设时应 增加其数量, 提高其服务半径, 考虑到公园的生态性、游 悡性和景观性的综合价值, 为人们创造更好的栖居环境。 连接廊道则分为两级一一级廊道和二级廊道。一级廊道 为穿越新城的高速路、快速干道和渭河、泮河沿岸, 具有 极为重要的生物多样性保护、生态涵养、生态防护等作用, 根据相关资料整理, 为保证两栖动物、鸟类和哺乳动物的 迁徙, 以及噪声隔离、防护林的建设, 廊道的宽度要大于 $100 \mathrm{~m}[22,23]$ 。二级廊道为新城内主干道及河流支流沿岸, 在建设时, 应充分考虑生态功能和游秝功能, 如加宽道路 绿化带, 形成林荫大道; 改建渠化河道, 恢复自然生态驳 岸, 修复生态系统等。

\section{2. 加强小场地的建设}

小场地在绿色基础设施网络中具有重要作用, 尤其是 对于一些迁徙距离较远的物种和景观破碎化严重缺乏大 型生态源地的地区。在生态上, 小场地可以为动物提供暂 时的休息场所, 改善微气候; 在游悡方面, 小场地可以是 
街头绿地、居住区绿地等小面积的绿色空间, 可以为居民 就近休闲、锻炼等提供场所, 在城市建设中具有重要意义。 所以, 应加强研究区内小场地的建设, 在适当位置增设小 场地, 提高斑块间的连通度, 增加踏脚石的数量和降低踏 脚石斑块间的距离将有利于提高物种在迁移过程中的成 功率和存活率, 还可为居民创造多样美好的游憩空间, 在 生态用地有限的城市建成区增加绿量, 提高景观多样性。

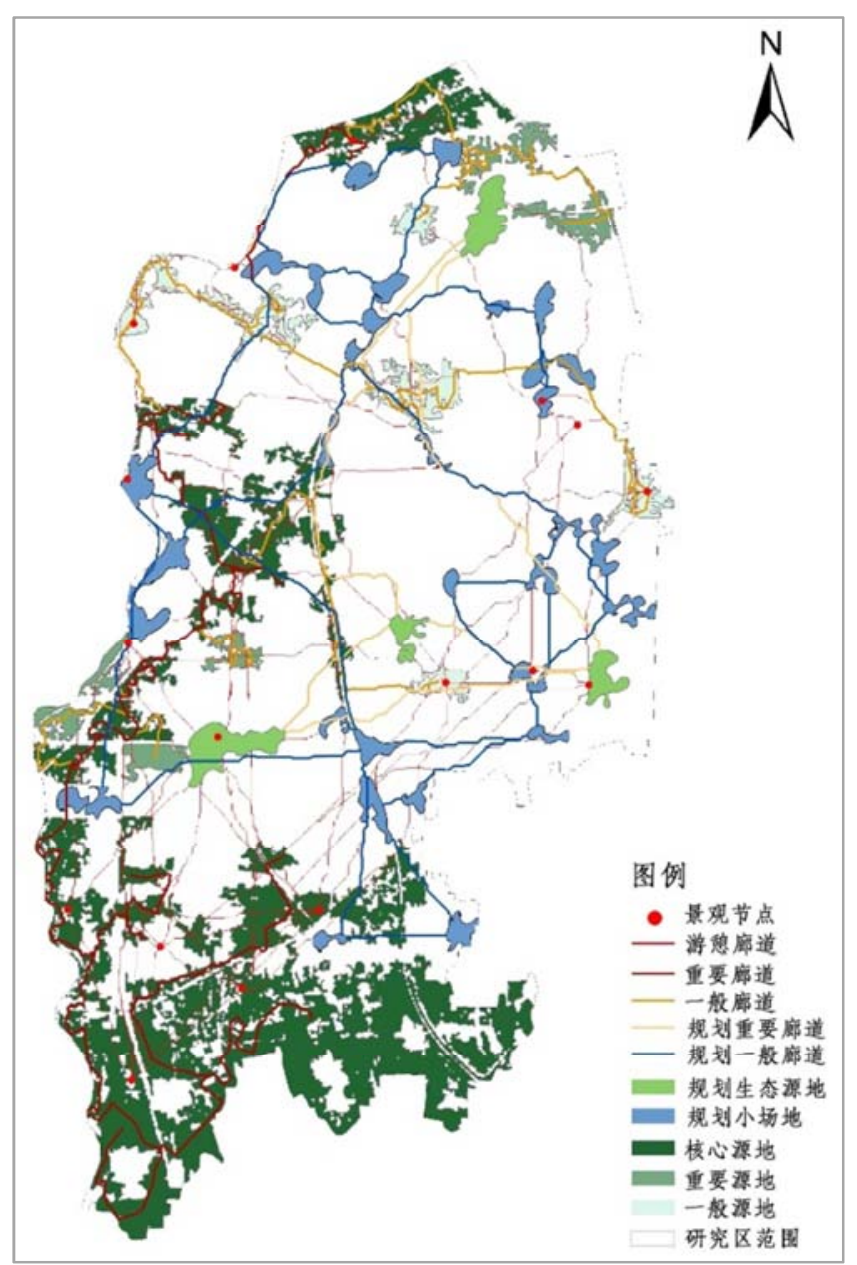

图5 规划后GI网络格局。

\section{3. 提高综合GI网络的完整性}

综上所述, 提高研究区的 GI网络的完整性迫在眉睫, 根据《西咸西区浅东新城控制性详细规划（2020-2030）》 规划文件及土地利用现状, 在研究区内增补了 4 个网络中 心和 31 个小场地, 尤其针对新城中部和东部生态斑块确实 的现状, 选取草地、园地及水体等作为网络中心及小场地, 对水体主的水域生态潜力㸚块进行绿化恢复和生态基础 设施建设, 对草地、林地等潜力斑块, 以恢复和修复为主, 以提高其生态服务价值。并利用ArcGIS软件中的成本连通 性（Cost Connectivity）工具, 对所增补的网络中心及小 场地进行潜在廊道识别与构建, 并结合人们的游䛻及休闲 需要, 在研究区内增加了街头绿地、社区公园等绿地空间, 并与生态网络相叠加, 形成综合价值的GI网络, 提高了研 究区GI网络的完整性（图5）。

\section{5. 结论与讨论}

\section{1. 结论}

绿色基础设施网络可以连接大型自然生态源地和城 市公园及其他绿色空间, 是生物多样性保护和防止栖息地 破碎化的绿色景观网络, 它对维持和保护城市自然生命支 持系统, 满足当代人类生活、休闲需求, 指导城市可持续 发展具有重要意义。优化绿色基础设施网络, 可以增强整 体景观网络的稳定性, 为区域内的生物迁徙、能量交流等 提供空间, 对整体生态环境结构的优化和保护具有重要意 义。

本研究首先通过MSPA法对研究区内的绿色基础设施 构成要素进行识别和分类, 并且提取出面积大于 3 公顷的 生态斑块作为网络中心（生态源地）, 再利用Confor软件 中的 $\mathrm{dPC}$ 和 $\mathrm{dIIC}$ 两个指数对网络中心和桥接区之间的连通 性进行评价, 提取 $\mathrm{dPC}$ 指数大于 1 的斑块作为核心源地和极 重要桥接区, 这种方法避免了以往通过人为选取景区或公 园作为源地的主观性; 然后基于绿色基础设施的功能复合 性, 利用MCR模型分别识别和构建了研究区内的生态廊道 和游憩廊道, 考虑到生态廊道和游㕷廊道影响因素的差异 性, 选取不同的阻力因素, 利用专家打分法分别构建了不 同的阻力面, 并将MSPA景观连通性分析和最小累积阻力 有机结合, 创新性的提出GI 网络构建的新方法。并根据 研究结果结合政府规划文件, 对研究区内的GI网络进行优 化, 选取适宜的地段增补网络中心和小场地, 实现GI网络 的最优连通性和完整性。

\section{2. 讨论}

本文将MSPA方法和MCR进行结合构建绿色基础设 施网络, 打破了传统仅利用MCR模型的局限性, MSPA模 型仅利用土地利用类型数据就可实现对一地区的生态用 地分布情况, 并且可以实现生态斑块的分类, 提取核心区、 边缘区、桥接区、孤岛等具有重要生态意义的斑块类型, 是一种将复杂系统简化的研究方法。但是MSPA法对尺度 比较敏感, 如何确定研究区的栅格大小目前没有统一的科 学方法, 本研究根据研究区面积选取 $10 \mathrm{~m} * 10 \mathrm{~m}$ 的大小, 对 MSPA 的尺度问题还应做进一步的研究和探讨。在进行景 观连通性计算时, 根据前人论文研究选用了阈值距离为 $500 \mathrm{~m}$, 连通率为 0.5 , 这个参数设置还需有更科学的参考。 总而言之, 本文采用了多种方法对绿色基础设施网络的构 建进行创新, 但是在参数设置时仍有一些问题需要进一步 深化。

\section{参考文献}

[1] 仇江啸, 王效科, 逯非, 欧阳志云, 郑华. 城市景观破碎 化格局与城市化及社会经济发展水平的关系一一北京 城区为例. 生态学报, 2012, 32(9): 2659-2669.

[2] 谢高地. 城市生物多样性保护与生态系统服务供给 [J]. 环 境保护, 2015, 43(5): 25-28. 
[3] 许峰, 尹海伟, 孔繁花,等. 基于MSPA与最小路径方法的 巴中西部新城生态网络构建 [J]. 生态学报, 2015(19):6425-6434.

[4] 吴伟, 付喜娥. 绿色基础设施概念及其研究进展综述 [J]. 国际城市规划, 2009(5):67-71.

[5] 邱瑶, 常青, 王静. 基于MSPA的城市绿色基础设施网络规 划——深圳市为例 [J]. 中国园林，2013， 029(005):104-108.

[6] 马克·A.贝内迪克特, 爱德华· $\cdot$ ·麦克马洪. 绿色基础设施: 连接景观与社区 $[\mathrm{M}]$. 黄丽玲, 杜秀文, 朱 强, 等译. 北 京：中国建筑工业出版社, 2010: 1-15.

[7] 王云才, 申佳可, 彭震伟,等. 适应城市增长的绿色基础设 施生态系统服务优化 [J]. 中国园林, 2018, 000(010):45-49.

[8] Saroinsong F, Harashina K, Arifin H, et al. Practical application of a land resources information system for agricultural landscape planning $[\mathrm{J}]$. Landscape \& Urban Planning, 2007, 79(1): 38-52.

[9] Helmund P. Quabbin to Wachusett Wildlife Corridor Study[D]. Cambridge: Harvard University, 1989.

[10] 贾行飞, 戴菲.我国绿色基础设施研究进展综述 [J]. 风景园林, 2015(8): 118-124.

[11] 王晶晶，尹海伟，孔繁花. 多元价值目标导向的区域绿色 基础设施网络规划——古黄河周边区域为例 [J]. 山东师 范大学学报(自然科学版), 2016, 31(003):77-83.

[12] 黄河, 余坤勇, 高雅玲, 等. 基于MSPA的福州绿色基础设 施网络构建 [J]. 中国园林, 2019, 035(011):70-75.

[13] Wickham J D, Riitters K H, Wade T G, et al. A national assessment of green infrastructure and change for the conterminous United States using morphological image
processing[J]. Landscape and Urban Planning, 2010, 94(3): 186-195.

[14] 于亚平, 尹海伟, 孔繁花, 等.基于MSPA的南京市绿色基 础设施网络格局时空变化分析 [J].生态学杂志, 2016, 35(6): 1608-1616.

[15] 陈静、左翔、彭建松、区智、孙正海. 基于MSPA与景观连 通性分析的城市生态网络构建——以保山市隆阳区为例 [J]. 西部林业科学, 2020, v.49;No.189(04):123-128+146.

[16] 杨志广, 蒋志云, 郭程轩, 等. 基于形态空间格局分析和 最小累积阻力模型的广州市生态网络构建 [J] . 应用生态 学报, 2018, 29(10): 3367-3376.

[17] Vogt P, Kurt H, Riitters I M, et al. Mapping landscape corridors[J]. Ecological Indicators, 2007, 7(2): 481-488.

[18] Soille P, Vogt P. Morphological segmentation of binary patterns[J]. Pattern Recognition Letters, 2009, 30(4): 456-459.

[19] Richard T T. Forman. Land mosaics: The ecology of landscapes and regions[M]. Cambridge University Press, 1995.

[20] Walker R, Craighead L. Analyzing wildlife movement corridors in Montana using GIS. Environmental Sciences Research Institute. Proceedings of the1997 International ArcI nfo Users' Conference, December 10, 2002.

[21] 袁艳华, 徐建刚, 张翔. 基于适宜性分析的城市遗产廊道 网络构建研究—以古都洛阳为例 $[\mathrm{J}]$. 遥感信息, 2014, 029(003):117-124.

[22] 贾铠针. 新型城镇化下绿色基础设施规划研究 [D]. 天津大 学, 2015 .

[23］《上海市生态廊道体系规划》（2017-2035）。 